\begin{tabular}{lll}
\hline IZVORNI & UDK: 378.091.3:81'243:796.06:33 & Primljen: 25. 10. 2020. \\
ZNANSTVENI RAD & DOI: $10.22210 /$ strjez/50-1/2 & Prihvaćen: 2. 2. 2021.
\end{tabular}

\title{
Kvantitativna analiza studentske procjene važnosti stranih jezika u sportskome menadžmentu
}

\author{
Darija Omrčen \\ darija.omrcen@kif.hr \\ Kineziološki fakultet Sveučilišta u Zagrebu \\ Magdalena Mihovec \\ mihovec7@gmail.com \\ T. O. MODA-IN
}

Cilj je istraživanja bio utvrditi kako budući kineziolozi procjenjuju važnost znanja ponuđenih 15 stranih jezika za rad u sportskome menadžmentu. Uzorak ispitanika sastojao se od 70 studenata i studentica Kineziološkog fakulteta Sveučilišta u Zagrebu. Rezultati su pokazali da su ispitanici najčešće i prosječno najveći broj godina učili engleski i njemački jezik. Dva je strana jezika učio najveći broj ispitanika (62,86 \%), dok je tri strana jezika učilo $20 \%$ ispitanika. Tek je $10 \%$ ispitanika učilo samo jedan strani jezik, a najmanji je postotak ispitanika učio četiri strana jezika $(7,14 \%)$. Ispitanici su znanje engleskog i njemačkog jezika procijenili najvažnijim za rad u sportskome menadžmentu. Faktorskom analizom dobivene su tri latentne dimenzije koje su protumačene aspektom turizma, sportskom uspješnosti i jačinom ekonomije. Multivarijatnom analizom varijance nisu utvrđene razlike među ispitanicima u procjeni važnosti znanja 15 stranih jezika s obzirom na broj stranih jezika koje su učili.

Ključne riječi: procjena važnosti, sportski menadžment, strani jezici, turizam 


\section{UVOD}

Sportski turizam gospodarska je djelatnost u kojoj Hrvatska kao turistička zemlja nastoji pronaći i zauzeti što bolje mjesto. Izravan i neizravan doprinos putovanja i turizma svjetskom bruto domaćem proizvodu (BDP) iznosio je 8,9 trilijuna američkih dolara (USD) u 2019. (World Travel \& Tourism Council, n. d.), a ukupan je međunarodni turistički izvoz u 2019. iznosio 1,7 trilijuna USD (UNWTO - World Tourism Organization, 2019: 2). Promatrano na globalnoj razini, među zemljama s najvećim udjelom turizma u BDP-u za 2019. nalaze se Makao (50,2 \%), Maldivi (32,5 \%) i Aruba (32 \%) (Statista, n. d.), dok je Hrvatska s 20 \% (Ministarstvo turizma RH, 2020: 43) na vrhu europskih zemalja prema udjelu turizma u BDP-u (Orsini i Ostojić, 2018). Globalno je sportsko tržište u 2018. vrijedilo 488,5 milijarda USD (Business Wire, 2020). Prema tom izvoru, natjecateljski sport generira oko 250 milijarda USD godišnje, a spoj tih dviju djelatnosti - sportski turizam, prema World Sport Tourism Show (n. d.), predstavlja $10 \%$ ukupne svjetske turističke industrije s prometom od oko 800 milijarda USD. Taj izvor kao glavne emitivne države sportskih turista navodi Veliku Britaniju, Njemačku, Italiju, Španjolsku, Dansku, Švedsku i Finsku. Istraživanja o sportskom turizmu provode istraživači u cijelom svijetu (De Knop i Van Hoecke, 2003; Gibson, 1998; Harrison-Hill i Chalip, 2005; Uvinha i sur., 2018) pa tako i u Hrvatskoj (Bartoluci, 1995; Škorić, 2008). Pojedini autori zastupaju i tezu da su velika sportska događanja način kako doprinijeti razvoju turizma (Zhang i McCornac, 2014: 114). Što se Hrvatske tiče, o povezanosti turizma i sporta govori i niz istraživanja TOMAS koje provodi Institut za turizam o, među ostalim, stavovima turista koji posjećuju Hrvatsku. Prema zadnjem istraživanju u nizu, u 2017. je 54,9 \% anketiranih turista za posjet Hrvatskoj bilo motivirano (pasivnim) odmorom (opuštanjem) na moru, a slijedila su nova iskustva i doživljaji (31,1 \%), gastronomija (29\%), upoznavanje prirodnih ljepota $(26,2 \%)$, zabava $(24,2 \%)$ te na šestome mjestu bavljenje sportom i rekreacijom (19,8 \%) (Marušić, Čorak i Sever, 2017: 31). Ponuda sporta u turizmu u Hrvatskoj je u stalnom porastu (usp. Bartoluci, Škorić i Starešinić, 2016).

Razvoj sportskog turizma rezultirao je razvojem brojnih novih poslova u turizmu, a jedan je od njih posao sportskog menadžera, koji sve češće postaje predmetom istraživanja - od znanja koja sportski menadžeri moraju imati do kompetencija (Retar, Plevnik i Kolar, 2013) i komunikacijskih vještina (usp. Çiftçi i Mirzeoğlu, 2014; Çolak i sur., 2018; Ko, Henry i Kao, 2011; Škorić, 2018). S obzirom na 'preklapanje' turizma i sporta u brojnim segmentima, zajednička su im i pojedina znanja, vještine i kompetencije 
u njima zaposlenih stručnjaka. Jedna od važnih kompetencija jest i znanje stranih jezika (usp. Jovanova-Simeva, 2015; Kostić Bobanović i Gržinić, 2011; Orel Frank, 2016; Škorić, 2018). Posljedično se pojavljuju i istraživanja u kojima su predmeti istraživanja bili: važnost stranih jezika u turizmu (Čolić i Tomić, 2013; Leslie i Russell, 2005), analiza potreba za znanjem stranih jezika, osobito engleskog, u turizmu (Prachanant, 2012), potreba za razvijanjem jezičnih kompetencija u stranom jeziku (Menike i Pathmalatha, 2015) te stavovi studenata koji se obrazuju za rad u turizmu (Sindik i Božinović, 2013), sportskom turizmu (Amirovna i Rustamovna, 2014) i sportskom menadžmentu (Bondrea, 2012; Sunay i ve Çayci, 2008). Danas je znanje stranog/stranih jezika jedan od važnih uvjeta na brojnim radnim mjestima, a prilikom zapošljavanja na nematičnome govornom području, poznavanje službenog jezika zemlje na čijem se području zaposlenik želi zaposliti jedan je od važnih čimbenika koji poslodavac uzima u obzir (Chiswick, 2008; Chiswick i Miller, 1995, 2010; Dustmann i Fabbri, 2003).

\section{ANALIZA STUDENTSKE PROCJENE VAŽNOSTI STRANIH JEZIKA U SPORTSKOME MENADŽMENTU}

\subsection{Cilj istraživanja i uzorak ispitanika}

Cilj je istraživanja bio utvrditi kako budući kineziolozi procjenjuju važnost znanja 15 odabranih stranih jezika (češki, engleski, francuski, japanski, kineski, korejski, mađarski, norveški, njemački, poljski, ruski, slovački, španjolski, švedski i talijanski) za rad u sportskome menadžmentu. Uzorak se sastojao od 70 ispitanika (44 studenta i 26 studentica) četvrte i pete studijske godine na Kineziološkom fakultetu Sveučilišta u Zagrebu. Od ukupnog broja ispitanika njih je petero tijekom života učilo njemački, četvero talijanski, dok je 61 ispitanik učio engleski kao prvi strani jezik. Zajedničko je svim ispitanicima bilo da su svi učili engleski kao strani jezik.

\subsection{Metodologija}

Ispitanici su najprije ispunili dio mjernog instrumenta odgovorima na pitanja o broju stranih jezika koje su tijekom života učili te o broju godina učenja svakog od tih jezika, za što su izračunate srednje vrijednosti, a navedene su i najniže i najviše vrijednosti. Zatim su izračunate frekvencije i postotci broja te kombinacije stranih jezika koje su ispitanici učili. Ispitanici su procijenili važnost znanja svakog od 15 odabranih jezika na ljestvici Likertova tipa od pet stupnjeva (od 1 - nije ni najmanje važan do 5 - izrazito je važan). 
Jezici čija se važnost za rad sportskih menadžera procjenjivala mjernim instrumentom odabrani su prema tri kriterija. Prvi se kriterij odnosio na učestalost učenja pojedinih stranih jezika u osnovnim i srednjim školama u Hrvatskoj (Prilog 1.), te je prema njemu u mjerni instrument uključeno devet jezika: engleski, njemački, talijanski, francuski, španjolski, mađarski, češki, slovački i ruski. S obzirom na to da je arapski jezik učilo ukupno (osnovne i srednje škole) manje od 100 učenika, taj jezik nije uključen u mjerni instrument.

Drugi se kriterij odnosio na pripadnost drugih indoeuropskih jezika germanskoj i slavenskoj skupini. Na temelju njega su u mjerni instrument uključeni švedski i norveški - jezici germanske skupine kojoj pripadaju i engleski i njemački jezik, uvršteni u istraživanje prema prvom kriteriju, te poljski kao jezik iz slavenske skupine kojoj pripadaju češki, slovački i ruski - također uvršteni u istraživanje prema prvom kriteriju. Švedski i norveški uključeni su i na temelju trećeg kriterija, kao i dijelom poljski - zbog toga što Poljaci danas u Hrvatskoj sve češće otvaraju različite poslovne subjekte (Rajković Iveta i Babić, 2018: 171).

Treći je kriterij ekonomski aspekt, odnosno snaga ekonomije neke zemlje, te su u istraživanje uključeni i azijski jezici: kineski (druga najjača svjetska ekonomija s obzirom na BDP u 2019. - World Bank, 2020), japanski (treća najjača svjetska ekonomija s obzirom na BDP u 2019. - World Bank, 2020) i korejski (Južna Koreja, 12. na ljestvici zemalja s obzirom na BDP u 2019. - World Bank, 2020). Taj se kriterij temeljio na mogućoj motiviranosti ispitanika za učenjem jezika koji se govore u razvijenim zemljama svijeta jer one, zbog vrlo dobroga financijskog statusa, izdvajaju znatna financijska sredstva za sport pa stoga učenje službenih jezika tih zemalja može posljedično utjecati na buduću zapošljivost u njima. K tomu, zajednički nazivnik Švedske (23. na ljestvici zemalja s obzirom na BDP u 2019. - World Bank, 2020), Norveške (30. na ljestvici zemalja s obzirom na BDP u 2019. - World Bank, 2020), Poljske (21. na ljestvici zemalja s obzirom na BDP u 2019. - World Bank, 2020), Kine, Japana i Južne Koreje jest taj da se te zemlje nalaze među 20 zemalja s ukupno najviše osvojenih olimpijskih medalja od 1896. do 2018. (usp. World Population Review, 2020).

Za svaki stupanj procijenjene važnosti znanja tih 15 stranih jezika izračunate su frekvencije i postotci. Zatim je provedena faktorska analiza koja uključuje varimax rotaciju i Kaiserovu normalizaciju za 15 jezičnih varijabla kako bi se dobila latentna struktura upotrijebljenoga mjernog instrumenta čija je interna konzistentnost određena Cronbachovim koeficijentom alfa. Izračunate su i prosječne srednje vrijednosti procjene važnosti znanja onih 
stranih jezika koji su imali najviše korelacije s nekim od triju faktora. Prvi je cilj faktorske analize bio utvrditi pozadinu, odnosno implicitne razloge za procjenu njihove važnosti. Drugi je cilj faktorske analize bio preko skorova dobivenih faktora kao zavisnih varijabla utvrditi, putem multivarijatne analize varijance (MANOVA) s razinom značajnosti od $\mathrm{p}<0,05$, postoje li razlike među ispitanicima $\mathrm{u}$ latentnim dimenzijama procjene važnosti znanja 15 stranih jezika uključenih u analizu s obzirom na broj stranih jezika (1, 2, 3 i 4) koje su učili tijekom života.

\section{REZULTATI I RASPRAVA}

\subsection{Deskriptivna statistika}

Tablica 1. pokazuje vrijednosti učestalosti učenja svakog od devet stranih jezika koje su ispitanici učili tijekom života. Neočekivana su dva podatka: učenje japanskog i kineskog jezika. No dok se za učenje japanskog može reći da je neočekivan rezultat, boljim poznavateljima programa integriranoga preddiplomskog i diplomskog sveučilišnog studija kineziologije podatak o tome da su tri ispitanika učila kineski ne predstavlja iznenađenje. Naime, Kineziološki fakultet u Zagrebu svojim studentima omogućuje odabir izbornog predmeta pod nazivom Kineski jezik (u akademskoj 2020./2021. $\mathrm{u}$ X. semestru, i to $\mathrm{u}$ fondu od 30 sati $-15 \mathrm{P}+15 \mathrm{~V})$. Svake se akademske godine formira barem jedna grupa studenata za taj kolegij.

Tablica 1. Učestalost učenja svakog od devet stranih jezika koje su učili ispitanici iz uzorka

\begin{tabular}{l|c|c|c|c|c|c|c|c|c}
\hline STRANI JEZICI KOJE SU UČILI ISPITANICI & EN & NJ & FR & TA & ŠP & ČE & KI & SL & JA \\
\hline Frekvencija & 70 & 51 & 2 & 21 & 5 & 2 & 3 & 1 & 2 \\
\hline
\end{tabular}

EN - engleski, NJ - njemački, FR - francuski, TA - talijanski, ŠP - španjolski, ČE - češki, KI - kineski, SL slovenski, JA - japanski

Jedan od mogućih razloga za interes studenata kineziologije za kineski jest činjenica da je Kina među vodećim sportskim zemljama svijeta - u popisu iz 2018. nalazi se na šestome mjestu prema broju ukupno osvojenih olimpijskih medalja (World Population Review, 2020), stoga je vrlo zanimljiva studentima kineziologije. Drugi je mogući razlog ekonomski - Kina je druga najjača svjetska ekonomija koja izdvaja znatna sredstva, među ostalim, i za sport. Tako se objedinjuje vjerojatna motiviranost studenata koji žive u tzv. 'maloj' ekonomiji - Hrvatska je na 79. mjestu na ljestvici zemalja s obzirom na BDP u 2019., za učenjem kineskog. 
Navedeno povlači za sobom i tumačenje rezultata o dva ispitanika koji su učili japanski kao strani jezik. Moguće je da taj rezultat nije potpuno slučajan ni neočekivan. Naime, studenti kineziologije prate velika sportska događanja poput svjetskih prvenstava i Olimpijskih igara i upoznati su sa sportskim postignućima sportaša iz raznih zemalja. A Japan je na visokom 11. mjestu po broju ukupno osvojenih olimpijskih medalja (World Population Review, 2020), stoga je vjerojatno kako su neki ispitanici upoznati sa sportskim uspjesima japanskih sportaša. K tomu je japanska ekonomija jedna od najjačih na svijetu - prema BDP-u u 2019. bila je na trećem mjestu, iza SAD-a i Kine (World Bank, 2020). Razlozi za učenje japanskog mogli bi biti rezultat objedinjene percepcije Japana kao ekonomske i sportske velesile (kao i u slučaju s Kinom), što je dovoljan razlog za razmišljanje o mogućem zapošljavanju na poslovima sportskog menadžera u toj zemlji.

Ispitanici su, očekivano, prosječno najviše godina učili engleski i njemački jezik (Tablica 2.), što je u skladu s podatcima da se radi o jezicima koje hrvatski osnovnoškolci i srednjoškolci najčešće uče kao strani jezik (Prilog 1.). No neočekivan je bio podatak o malom broju godina učenja jezika poput talijanskog i francuskog (potonji tek 0,04 godine). Podatak o 23 godine učenja nekoga stranog jezika ističe se kao maksimalna vrijednost, no radi se o izoliranom slučaju - ne radi se o izvornom govorniku talijanskog, već o ispitaniku koji je talijanski kao strani jezik učio gotovo cijeli život.

Tablica 2. Broj godina učenja svakog od devet stranih jezika koje su učili ispitanici iz uzorka

\begin{tabular}{l|c|c|c|c|c|c|c|c|c}
\hline STATISTIČKA VRIJEDNOST & EN & NJ & TA & KI & JA & ČE & SL & ŠP & FR \\
\hline Srednja vrijednost & 10,55 & 4,77 & 1,96 & 1,50 & 1,50 & 1 & 1 & 0,11 & 0,04 \\
\hline Minimalna vrijednost & 5 & 0 & 0 & 0.5 & 1 & 1 & 1 & 0 & 0 \\
\hline Maksimalna vrijednost & 18 & 15 & 23 & 2 & 2 & 1 & 1 & 2 & 2 \\
\hline
\end{tabular}

EN - engleski, NJ - njemački, FR - francuski, TA - talijanski, ŠP - španjolski, ČE - češki, KI - kineski, SL slovenski, JA - japanski

Drugim riječima, u Tablici 2. nisu zanimljivi veliki, već mali brojevi. Jedan je od tih malih brojeva podatak o prosječnom broju godina učenja španjolskog - taj je broj godina učenja izrazito nizak u odnosu na nizak, ali ipak uočljiv broj ispitanika $(\mathrm{n}=5)$ koji su učili taj strani jezik. Ta je disproporcija za učenje češkog jezika bila manja, a za razliku od disproporcije između učestalosti i godina učenja španjolskog, broj godina učenja slovenskog jezika (1) bio je proporcionalan broju ispitanika koji su ga učili (1) (usp. Tablica 1. i Tablica 2.).

Podatci prikazani u Tablici 3. osobito privlače pozornost. Tek je sedam (10 \%) ispitanika tijekom života učilo samo jedan strani jezik, dok ih je 62,86 \% 
učilo dva, a 20 \% tri strana jezika. Najmanji je postotak ispitanika učio četiri strana jezika, no taj je broj $(7,14 \%)$ bio tek malo niži od broja onih koji su učili samo jedan strani jezik. Stoga taj rezultat valja promatrati kao važan podatak u pozitivnom smislu. Očigledno je da su studenti kineziologije tijekom života pridavali relativno veliku važnost učenju stranih jezika, za što postoje dva moguća razloga. Prvi je zanimanje za sport od rane mladosti, i to ne samo u mikrookruženju već i na međunarodnoj razini. U potonjem je slučaju znanje stranih jezika (osobito engleskog, ali i nekih drugih) ključno za pristup raznovrsnim informacijama - od važnih podataka o trenažnom procesu i utjecaju sporta (rekreativni i natjecateljski sport) na zdravlje do načela zdrave prehrane, utjecaja tjelovježbe na mentalno zdravlje pojedinca i sl. Drugi je aspekt izravno povezan s prvim i leži u njegovoj osnovi. Radi se o globalnom karakteru sporta (kineziologija, znanost o ljudskom kretanju, proučava i sport) kao društvenom fenomenu, što podrazumijeva svjetske sportske (i tjelovježbene) trendove, kao i komunikaciju, npr. putem brojnih društvenih mreža, među ljudima koji se sportom bave iz rekreativnih razloga, kao i komunikaciju među sportašima i o sportašima iz svih dijelova svijeta, što u konačnici ukazuje na raznolikost jezika kojima svi sudionici u komunikaciji govore.

Tablica 3. Broj stranih jezika koje su učili ispitanici iz uzorka

\begin{tabular}{l|c|c}
\hline BROJ STRANIH JEZIKA & Frekvencija & Postotak \\
\hline Jedan & 7 & 10,00 \\
\hline Dva & 44 & 62,86 \\
\hline Tri & 15 & 20,00 \\
\hline Četiri & 5 & 7,14 \\
\hline
\end{tabular}

Usporede li se podatci iz Tablice 3. s podatcima iz Tablice 4., ističe se rezultat da je čak 48,57 \% ispitanika uz engleski učilo njemački jezik. Taj se podatak može protumačiti time da brojni hrvatski sportaši žive i rade (barem u jednom dijelu života) u Njemačkoj ili Austriji. Primjerice, rukomet je sport nastao na području današnje sjeverne Njemačke, južne Švedske i Danske. Prva pravila rukometa napisana su na njemačkom i taj je sport vrlo popularan u Njemačkoj. Stoga ne čudi činjenica da je niz hrvatskih rukometaša i rukometnih trenera proveo dio svoje karijere u toj zemlji. Austrija je zemlja skijanja u kojoj su intenzivno trenirali Janica i Ivica Kostelić, a tisuće hrvatskih građana provode dio svog odmora u toj zemlji njemačkoga govornog područja, a potreba za barem minimalnim znanjem osnova njemačkog jezika postaje redovita pojava. Što se pak profesionalne budućnosti i zapošljivosti kineziologa tiče, zemlje njemačkoga govornog područja su za njih 
zanimljive najčešće zbog sportskih razloga (natjecateljska i/ili trenerska karijera) s kojima su povezani i financijski razlozi. Kao treće, a to je pak razlog koji je implicitan, njemački je jezik po broju prvih govornika najrašireniji jezik u Europi, pa ne čudi učestalost učenja njemačkog kao stranog jezika.

Sljedeća najučestalija kombinacija stranih jezika koje su ispitanici učili bila je kombinacija engleskog i talijanskog jezika. Osim što rezultat proistječe, s jedne strane, iz činjenice da jedan dio studenata kineziologije dolazi iz područja Hrvatske u kojima je učenje talijanskog češće od učenja drugih stranih jezika (osim, možda, engleskog), a s druge i činjenice da brojni hrvatski sportaši i kineziolozi provode dio svoje profesionalne karijere - igračke ili trenerske, u Italiji, takav rezultat može biti i posljedica želje za praćenjem talijanskih sportskih događanja, primjerice, nogometnih utakmica Serie A. No precizna identifikacija razloga ostaje na razini pretpostavke jer se u istraživanju nisu utvrđivali motivi za učenjem stranog jezika.

Tablica 4. Strani jezici/kombinacije stranih jezika koje su učili ispitanici iz uzorka

\begin{tabular}{|c|c|c|}
\hline STRANI JEZICI / KOMBINACIJE STRANIH JEZIKA & Frekvencija & Postotak \\
\hline EN & 7 & 10 \\
\hline $\mathrm{EN}+\mathrm{NJ}$ & 34 & 48,57 \\
\hline $\mathrm{EN}+\mathrm{TA}$ & 8 & 11,43 \\
\hline $\mathrm{EN}+\mathrm{FR}$ & 1 & 1,43 \\
\hline $\mathrm{EN}+\mathrm{KI}$ & 1 & 1,43 \\
\hline $\mathrm{EN}+\mathrm{TA}+\mathrm{S} \mathrm{P}$ & 1 & 1,43 \\
\hline $\mathrm{EN}+\mathrm{NJ}+\mathrm{TA}$ & 8 & 11,43 \\
\hline $\mathrm{EN}+\mathrm{NJ}+\mathrm{S} P$ & 2 & 2,86 \\
\hline $\mathrm{EN}+\mathrm{NJ}+\mathrm{ČE}$ & 1 & 1,43 \\
\hline $\mathrm{EN}+\mathrm{NJ}+\mathrm{FR}$ & 1 & 1,43 \\
\hline $\mathrm{EN}+\mathrm{TA}+\mathrm{SL}$ & 1 & 1,43 \\
\hline $\mathrm{EN}+\mathrm{NJ}+\mathrm{TA}+\mathrm{JA}$ & 2 & 2,86 \\
\hline $\mathrm{EN}+\mathrm{NJ}+\mathrm{S} \mathrm{P}+\mathrm{C} E$ & 1 & 1,43 \\
\hline $\mathrm{EN}+\mathrm{NJ}+\mathrm{S} \mathrm{P}+\mathrm{KI}$ & 1 & 1,43 \\
\hline $\mathrm{EN}+\mathrm{NJ}+\mathrm{TA}+\mathrm{KI}$ & 1 & 1,43 \\
\hline
\end{tabular}

Legenda. EN - engleski, NJ - njemački, FR - francuski, TA - talijanski, ŠP - španjolski, ČE - češki, KI kineski, SL - slovenski, JA - japanski

Tablica 5. pokazuje da je važnost znanja engleskog procijenjena samo ocjenama $4(\mathrm{n}=2 ; 22,86 \%)$ i $5(\mathrm{n}=68 ; 97,14 \%)$, odnosno ispitanici su gotovo jednoglasno znanje engleskog jezika procijenili najvažnijim. Takvi 
rezultati nisu ništa novo i razlozi za takav stav su općepoznati, a jedan je od njih raširenost engleskog jezika u svijetu, tj. činjenica da je postao jezikom globalne komunikacije. Odmah iza njega se po procijenjenoj važnosti nalazi njemački jezik znanje kojeg je nešto više od polovine ispitanika procijenilo najvišom ocjenom, malo više od trećine vrlo dobrom ocjenom, a tek je 12,86 \% ispitanika znanje toga stranog jezika smatralo srednje važnim.

Tablica 5. Procjena važnosti znanja 15 stranih jezika

\begin{tabular}{|c|c|c|c|c|c|c|c|c|c|c|}
\hline \multirow{3}{*}{$\begin{array}{l}\text { PROCJENA } \\
\text { VAŽNOSTI } \\
\text { ZNANJA }\end{array}$} & \multicolumn{10}{|c|}{ STUPNJEVI ZA PROCJENU VAŽNOSTI UČENJA STRANOGA JEZIKA } \\
\hline & \multicolumn{2}{|c|}{1} & \multicolumn{2}{|c|}{2} & \multicolumn{2}{|c|}{3} & \multicolumn{2}{|c|}{4} & \multicolumn{2}{|c|}{5} \\
\hline & $\mathbf{f}$ & $\%$ & f & $\%$ & f & $\%$ & f & $\%$ & f & $\%$ \\
\hline Engleski & - & - & - & - & - & - & 2 & 2,86 & 68 & 97,14 \\
\hline Njemački & - & - & - & - & 9 & 12,86 & 24 & 34,28 & 37 & 52,86 \\
\hline Španjolski & 6 & 8,57 & 4 & 5,71 & 28 & 40,00 & 26 & 37,14 & 6 & 8,57 \\
\hline Talijanski & 4 & 5,71 & 4 & 5,71 & 28 & 40,00 & 24 & 34,28 & 10 & 14,28 \\
\hline Francuski & 8 & 11,43 & 11 & 15,71 & 23 & 32,86 & 22 & 31,43 & 6 & 8,57 \\
\hline Ruski & 12 & 17,14 & 14 & 20,00 & 27 & 38,57 & 10 & 14,28 & 7 & 10,00 \\
\hline Češki & 17 & 24,28 & 33 & 47,14 & 15 & 21,43 & 3 & 4,28 & 2 & 2,86 \\
\hline Slovački & 22 & 31,43 & 28 & 40,00 & 15 & 21,43 & 3 & 4,28 & 2 & 2,86 \\
\hline Poljski & 21 & 30,00 & 26 & 37,14 & 19 & 27,14 & 4 & 5,71 & - & - \\
\hline Mađarski & 24 & 34,28 & 27 & 38,57 & 15 & 21,43 & 4 & 5,71 & - & - \\
\hline Kineski & 19 & 27,14 & 20 & 28,57 & 17 & 24,28 & 7 & 10,00 & 7 & 10,00 \\
\hline Japanski & 25 & 35,71 & 20 & 28,57 & 15 & 21,43 & 8 & 11,43 & 2 & 2,86 \\
\hline Korejski & 28 & 40,00 & 23 & 32,86 & 14 & 20,00 & 4 & 5,71 & 1 & 1,43 \\
\hline Norveški & 24 & 34,28 & 19 & 27,14 & 18 & 25,71 & 6 & 8,57 & 3 & 4,28 \\
\hline Švedski & 24 & 34,28 & 19 & 27,14 & 15 & 21,43 & 9 & 12,86 & 3 & 4,28 \\
\hline
\end{tabular}

Rezultati procjene važnosti znanja njemačkog jezika iz hrvatske su perspektive također više-manje poznati: povijesna povezanost Hrvatske s Habsburškom Monarhijom, geografska i kulturološka orijentacija Hrvatske prema Njemačkoj i Austriji, poslovni odnosi Hrvatske i zemalja njemačkoga govornog područja itd. Tome valja dodati već spomenute percepcije o zapošljivosti kineziologa u njima u kontekstu sporta. U Tablici 5 . ističe se i izostanak najviše ocjene za procjenu važnosti znanja poljskog i mađarskog jezika, kao i neznatan broj ispitanika koji su važnost oba jezika procijenili sljedećom po redu najvišom ocjenom $(n=4 ; 5,71 \%)$. Što se prvog od ta dva jezika tiče, ispitanici su očigledno bili mišljenja da je zapošljivost u kontekstu sportskog menadžmenta u Poljskoj relativno niska. Što se pak 
Mađarske tiče, iako je i njezin utjecaj na Hrvatsku tijekom relativno dugoga povijesnog vremena ostavio trag na brojnim područjima društvenog života te, iako su pojedini sportovi u Mađarskoj bili vrlo rašireni, poput košarke, ispitanici važnost znanja mađarskog jezika očigledno nisu ocijenili visokim ocjenama. O razlozima takvog stava moguće je samo nagađati jer nacrt istraživanja nije predviđao dublju analizu te teme. Jedan je od mogućih razloga taj da ispitanici/kineziolozi zapošljavanje u Mađarskoj ne smatraju atraktivnim stoga što Mađarska nije u skupini bogatih svjetskih ekonomija - naime, nalazi se na 56. mjestu ljestvice prema BDP-u u 2019. (World Bank, 2020). K tome, mađarski jezik pripada ugrofinskim jezicima, što znači da nema nimalo sličnosti ni s jednim indoeuropskim jezikom, a vjerojatna posljedica tog jest da je relativno težak za učenje govornicima nekog od indoeuropskih jezika.

\subsection{Faktorska struktura mjernog instrumenta za procjenu važnosti učenja 15 stranih jezika}

Cronbachov koeficijent alfa bio je $\alpha=0,944$, tj. interna konzistentnost mjernog instrumenta za procjenu važnosti učenja navedenih 15 stranih jezika bila je vrlo visoka. Normaliziranom varimax rotacijom pod Kaiserovim kriterijem dobivena su tri faktora čije su svojstvene vrijednosti bile veće od $1(\lambda>1$ ) (Slika 1. i Tablica 6.). Prvi je faktor objašnjavao 57,404 \%, drugi faktor $12,630 \%$, a treći 7,095 \% ukupne varijance (Tablica 6.).

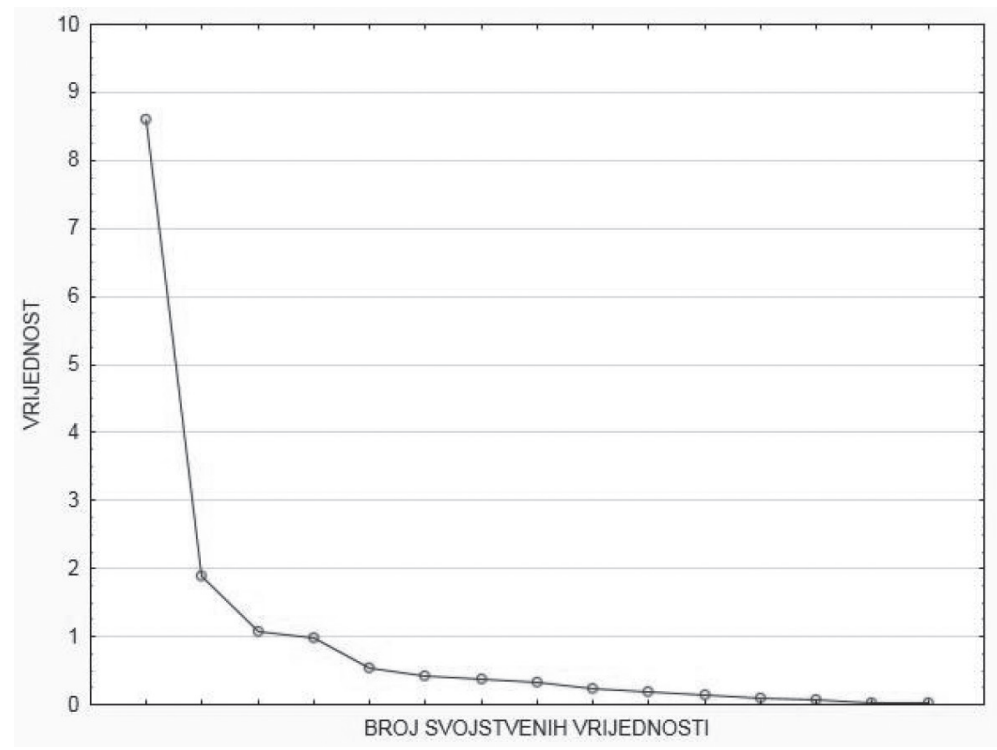

Slika 1. Prikaz broja svojstvenih vrijednosti većih od $1(\lambda>1)$ 
Tablica 6. Svojstvene vrijednosti veće od $1(\lambda>1)$ i postotak ukupne varijance

\begin{tabular}{l|c|c}
\hline FAKTOR & SVOJSTVENA VRIJEDNOST & POSTOTAK UKUPNE VARIJANCE \\
\hline 1 & 8,611 & 57,404 \\
\hline 2 & 1,894 & 12,630 \\
\hline 3 & 1,064 & 7,095 \\
\hline
\end{tabular}

Najviše korelacije s prvim faktorom uspostavile su varijable o važnosti učenja češkog, slovačkog, poljskog, mađarskog, norveškog i švedskog jezika (Tablica 7.). Varijabla važnost učenja korejskog jezika podijelila je svoju varijancu na dva faktora, i to na prvi $(r=0,694)$ i treći $(r=0,548)$. Iako je korelacija te varijable s prvim faktorom bila veća od korelacije s trećim, ta je varijabla ipak promatrana na trećem faktoru.

$\mathrm{S}$ obzirom na to da je 15 jezika uvršteno u mjerni instrument prema tri kriterija (učestalost učenja nekog jezika u osnovnim i srednjim školama Hrvatske; pripadnost pojedinih drugih europskih jezika germanskim i slavenskim jezicima te snaga ekonomije prema BDP-u), bilo je zanimljivo vidjeti jesu li dobiveni faktori korespondirali s tim kriterijima te hoće li biti potrebno napraviti više od jedne interpretacije triju latentnih dimenzija.

Tri su faktora prvo interpretirana na temelju navedena tri kriterija. Prvi bi se faktor mogao opisati kao faktor stranih jezika koji se rijetko uče ili se uopće ne uče kao strani jezici u Hrvatskoj zbog toga što su najviše korelacije s tim faktorom uspostavile varijable za procjenu važnosti znanja češkog, slovačkog, poljskog, norveškog, švedskog i mađarskog jezika. Taj bi faktor najvećim dijelom mogao odgovarati drugom kriteriju odabira jezika za mjerni instrument, a to je pripadnost pojedinih drugih jezika germanskim i slavenskim jezicima. Čini se kako u pozadini tog faktora stoji činjenica da se radi o slavenskim jezicima i jednome ugrofinskom jeziku koje učenici u osnovnim i srednjim školama u RH najrjeđe uče kao strane jezike, dok dvaju germanskih jezika, norveškog i švedskog, među stranim jezicima koje osnovnoškolci i srednjoškolci u RH uče uopće nema. Drugim riječima, najveći postotak varijance koji je opisivao prvi faktor može se pripisati činjenici da se radi o skupini jezika koji se uopće ne uče ili se uče rijetko kao strani jezici u Hrvatskoj. 
Tablica 7. Korelacije varijabla sa svakim od triju faktora

\begin{tabular}{l|c|c|c}
\hline VARIJABLA & FAKTOR 1 & FAKTOR 2 & FAKTOR 3 \\
\hline VU-EN & 0,022 & $\mathbf{0 , 3 9 9}$ & $-0,164$ \\
\hline VU-NJ & 0,216 & $\mathbf{0 , 8 0 5}$ & 0,132 \\
\hline VU-ŠP & 0,169 & $\mathbf{0 , 7 0 7}$ & 0,430 \\
\hline VU-TA & 0,143 & $\mathbf{0 , 7 7 7}$ & 0,350 \\
\hline VU-FR & 0,206 & $\mathbf{0 , 6 2 8}$ & 0,550 \\
\hline VU-RU & 0,282 & 0,373 & $\mathbf{0 , 7 0 3}$ \\
\hline VU-ČE & $\mathbf{0 , 9 1 4}$ & 0,205 & 0,212 \\
\hline VU-SČ & 0,926 & 0,196 & 0,225 \\
\hline VU-PO & $\mathbf{0 , 9 3 3}$ & 0,138 & 0,200 \\
\hline VU-MA & $\mathbf{0 , 8 6 3}$ & 0,135 & 0,269 \\
\hline VU-KI & 0,293 & 0,062 & $\mathbf{0 , 8 5 7}$ \\
\hline VU-JA & 0,517 & 0,107 & $\mathbf{0 , 7 6 9}$ \\
\hline VU-KO & $0,694^{*}$ & 0,169 & $\mathbf{0 , 5 4 8 *}$ \\
\hline VU-NO & $\mathbf{0 , 6 5 3}$ & 0,129 & 0,620 \\
\hline VU-ŠV & $\mathbf{0 , 6 6 3}$ & 0,168 & 0,569 \\
\hline OBJAŠNJENA VARIJANCA & 5,227 & 2,651 & 3,691 \\
\hline UKUPNA PROPORCIJA & 0,348 & 0,177 & 0,246 \\
\hline
\end{tabular}

*Varijabla je podijelila svoju varijancu na prvi i treći faktor.

VU - važnost učenja, ČE - češki, EN - engleski, FR - francuski, JA - japanski, KI - kineski, KO - korejski, MA - mađarski, NO - norveški, NJ - njemački, PO - poljski, RU - ruski, SČ - slovački, ŠP - španjolski, ŠV - švedski, TA - talijanski

S drugim faktorom, koji bi se inicijalno moglo nazvati faktorom stranih jezika koji se najčešće uče kao strani jezici u Hrvatskoj, najviše su korelacije uspostavile varijable za procjenu važnosti znanja engleskog, njemačkog, francuskog, talijanskog i španjolskog jezika.

$S$ trećim su dobivenim faktorom najveće korelacije imale varijable za procjenu važnosti znanja ruskog, kineskog, japanskog i korejskog jezika. Treći faktor evidentno reflektira ekonomski kriterij uključenja jezika u mjerni instrument za procjenu važnosti njihova znanja kao stranih jezika. Sve četiri zemlje u kojima se jezici s najvišim korelacijama s trećim faktorom govore kao službeni nalazile su se 2019. među 12 najjačih svjetskih ekonomija prema BDP-u (World Bank, 2020; Prilog 2.). Posljedično se ta latentna dimenzija može protumačiti kao faktor jakih svjetskih ekonomija, tj. kao faktor koji u svojoj pozadini nema jezični aspekt. 
Navedena tumačenja triju faktora nisu dala naslutiti moguću vezu između procjene važnosti znanja pojedinih stranih jezika i rada na poslovima sportskog menadžera - u Hrvatskoj ili u svijetu. Zbog toga se postavilo pitanje o tome postoji li još koja veza među trima faktorima i procjene važnosti znanja stranih jezika grupiranih na njima s najvećim korelacijama. Posljedično je valjalo promijeniti perspektivu i tumačenje triju faktora pokušati pronaći u drugome predmetnom području.

Primijenjen je drugačiji pristup analizi. Najprije su izračunate prosječne srednje vrijednosti procjena važnosti znanja svih jezika koji su uspostavili najviše korelacije s jednim od faktora. Tako je prosječna srednja vrijednost procjene važnosti znanja stranih jezika koji su imali najviše korelacije s prvim faktorom bila najniža i iznosila je 2,126. Prosječna srednja vrijednost procjene važnosti znanja stranih jezika koji su imali najviše korelacije s drugim faktorom bila je najviša $(3,848)$, dok je prosječna srednja vrijednost procjene važnosti znanja stranih jezika koji su imali najviše korelacije s trećim faktorom bila u sredini $(2,893)$.

Sljedeći je korak bio grupirati jezike koji su imali najviše korelacije s trima faktorima, tj. zemlje u kojima su ti jezici službeni, s obzirom na tri aspekta: 1) dijakronijski promatran prosječan broj osvojenih olimpijskih odličja (zaključno s 2018.), 2) prosječan BDP u 2019. i 3) prosječan broj turista koji su u 2019. posjetili Hrvatsku. Prvi aspekt govori o sportskim postignućima u sportskom svijetu, dok drugi govori o financijskim mogućnostima zemlje da financira određene društvene aktivnosti, koje zatim povratno generiraju nove ekonomske učinke, čime se, među ostalim, implicira i moguća zapošljivost, tj. moguća tržišna vrijednost rada u kontekstu sportskog menadžmenta. Dok olimpijska odličja nisu jedini pokazatelj uspjeha pojedinih sportaša i zemalja u svjetskim sportskim nadmetanjima (tu su i svjetska i kontinentalna prvenstva u pojedinim sportovima), drugi je pokazatelj bruto domaći proizvod, ključan u rangiranju snage ekonomije neke zemlje. U trećem, turističkom, aspektu moguća je implikacija da se opravdanost uključivanja turističkog aspekta $u$ analizu može potkrijepiti i percepcijom međuodnosa turizma i sporta - očigledno vrlo proširenom, a prema kojoj je, barem što se Hrvatske tiče, u srpnju 2020. Ministarstvu turizma u Hrvatskoj pridružen sport (koji se do tada nalazio u pod ingerencijom Ministarstva znanosti, obrazovanja i sporta). Iako se može činiti da je mogućnost zapošljavanja sportskih menadžera u hrvatskom turizmu - koji, iako u najvećoj mjeri podrazumijeva ljetne mjesece i boravak turista na hrvatskoj obali, uključuje i dolazak u Hrvatsku na razna sportska događanja, relativno skromna, ta mogućnost raste $\mathrm{s}$ obzirom na rast trenda motiviranosti 
posjeta Hrvatskoj zbog sporta i rekreacije (sa $7 \%$ u 2014. na 19,8 \% u 2017., Marušić i sur., 2017: 33), kao i zbog činjenice da su turisti nezadovoljni ponudom sportskih sadržaja (Marušić i sur., 2017: 46). Potonje otvara mogućnosti za daljnji razvoj, a time i za proširenje mogućnosti zapošljavanja kineziologa u sportskome menadžmentu na raznim poslovima. Pri tome valja na umu imati i ulogu sportskih postignuća hrvatskih sportaša i trenera, što povratno utječe i na percepciju Hrvatske kao sportske zemlje i zemlje sportskih stručnjaka. S obzirom na treći aspekt, prema publikaciji Turizam u brojkama 2019. (Ministarstvo turizma RH, 2020: 28-29), iz zemalja u kojima su jezici s najvišim korelacijama s prvim faktorom službeni jezici, Hrvatsku je u 2019. turistički posjetilo ukupno 3,198 milijuna turista (prosječno 533000 po zemlji s obzirom na službeni jezik), što je prema vrijednostima prikazanima u Prilogu 2. srednja promatrana vrijednost ukupnog broja turista od tri grupacije. Najviše je turista 2019. u Hrvatsku došlo turistički iz zemalja u kojima su službeni jezici oni s najvišim korelacijama s drugim faktorom - njih ukupno 7,718 milijuna (prosječno 695 333), dok je najmanji broj posjetitelja - 972000 (prosječno 243000 po zemlji), turistički došlo u Hrvatsku u 2019. iz zemalja u kojima su službeni jezici s najvišim korelacijama s trećim faktorom.

Zemlje kojih su službeni jezici imali najviše korelacije s prvim faktorom osvojile su prosječno najmanje olimpijskih odličja - 349,83; zemlje kojih su službeni jezici imali najviše korelacije s drugim faktorom osvojile su u prosjeku najviše odličja - njih 601,17; a zemlje kojih su službeni jezici imali najviše korelacije s trećim faktorom 497 olimpijskih odličja. Što se pak prosječnog BDP-a tiče, daleko najveći prosječan BDP u 2019. imale su Rusija, Kina, Japan i Južna Koreja (5 691 733,25 USD), kojih su službeni jezici imali najviše korelacije s trećim faktorom, dok su se na drugom mjestu po veličini prosječnog BDP-a (približno 1463420 USD) našle zemlje kojih su službeni jezici (engleski, njemački, francuski, talijanski, španjolski) imali najviše korelacije s drugim faktorom. S obzirom na treći, turistički aspekt, iz zemalja u kojima su službeni jezici s najvišim korelacijama s prvim faktorom Hrvatsku je 2019. turistički posjetio drugi po redu (Prilog 2.) najveći prosječni broj turista.

Analiza iz promijenjenog kuta pokazala je sljedeće: promatra li se prvi faktor, jasno je da se radi o službenim jezicima zemalja koje nisu među prvih dvadeset prema BDP-u (World Bank, 2020; Prilog 2.), što znači da zapošljivost u njima u kontekstu sporta i menadžmenta nije bila predmetom velikog zanimanja ispitanika (iako to vrijedi samo za dio zemalja kojih su službeni jezici imali najviše korelacije s prvim faktorom). Moguće je kako je 
procijenjena važnost jezika istaknutih na tome faktoru povezana i sa sportskim uspjesima, koji onda posljedično govore o zapošljivosti u sportskome menadžmentu. Međutim, povezanost $\mathrm{s}$ tim aspektom nije ujednačena. Naime, s jedne se strane Švedska, Norveška i Mađarska nalaze vrlo visoko, tj. među prvih deset zemalja prema broju osvojenih olimpijskih odličja Švedska na 6., Norveška na 9. a Mađarska na 10. mjestu (World Population Review, 2020), što bi potvrdilo motivaciju za zapošljavanjem u njima u kontekstu sportskog menadžmenta. No s druge se strane na tome faktoru nalaze službeni jezici zemalja (Poljska, Češka, Slovačka) koje se na ljestvici osvojenih olimpijskih odličja nalaze znatno niže - Poljska na 20., Češka na 33. a Slovačka na 45. mjestu. Skupno gledano, pokazalo se da je prosječan broj osvojenih olimpijskih odličja šest zemalja kojih su službeni jezici imali najviše korelacije s prvim faktorom bio najniži $(349,83)$, kao i prosječan iznos BDP-a. Što se trećeg aspekta tiče, iz zemalja u kojima su službeni jezici s najvišim korelacijama s prvim faktorom dolazi srednje velik broj turista. Za te su jezike ispitanici procijenili kako ih je najmanje važno znati, očigledno imajući u vidu činjenicu da mnogi stanovnici tih zemalja kao strane jezike uče - i relativno dobro se njima služe, jezike kojima se služi velik broj ljudi (engleski, njemački, talijanski itd.), a koji su uspostavili najviše korelacije s drugim od tri faktora. Stoga se činjenica da prvi faktor objašnjava velik postotak ukupne varijance može povezati s navedenim tumačenjem srednje veliki broj turista u 2019. i najniža procjena važnosti znanja jezika na tome faktoru. Nakon analize moguće je prvi faktor nazvati turističkim faktorom niske procijenjene važnosti znanja stranih jezika za rad u sportskome menadžmentu.

Drugi je faktor objašnjavao 12,630 \% ukupne varijance, tj. srednje velik postotak. Međutim, prosječna srednja vrijednost procijenjene važnosti znanja jezika koji su s njime imali najviše korelacije bila je najviša, zemlje kojih su to službeni jezici osvojile su prosječno najveći broj olimpijskih odličja, imaju srednje visok prosječan BDP, a iz njih je Hrvatsku u 2019. posjetio, ukupno gledano, najveći broj turista. Znanje stranih jezika koji su s tim faktorom uspostavili najviše korelacije ispitanici su procijenili najvažnijim za rad u sportskome menadžmentu. Takav je rezultat moguće potkrijepiti sljedećim činjenicama. Radi se o zemljama kojih su sportaši kroz povijest postigli velike sportske rezultate: američki su sportaši osvojili najveći broj olimpijskih medalja, a slijede Velika Britanija, Njemačka, Francuska i Italija, dok Španjolska dijeli 23. mjesto s Belgijom. No sportska postignuća pojedinih zemalja ( $t j$. sportaša iz tih zemalja) imaju kao posljedicu i odlazak hrvatskih sportaša i trenera na rad u te zemlje, a najčešće onih koji su ve- 
zani za ekipne sportove. Proslavljeni hrvatski nogometaš Luka Modrić igra u Španjolskoj u kojoj je jedno vrijeme igrao i poznati hrvatski rukometaš Mirza Džomba, dok je rukometašica Klaudija Bubalo jedno vrijeme igrala u Francuskoj. Nogometaš Niko Kranjčar igrao je u Austriji i Velikoj Britaniji, također nogometaš Ivica Olić u Njemačkoj (i Rusiji), košarkaši Toni Kukoč, Gordan Giriček i Dario Šarić u SAD-u, a hrvatske odbojkašice i odbojkaši najčešće odlaze igrati u Sloveniju, Francusku, Italiju i Njemačku. Što se pak sportskih trenera tiče, Velimir Kljaić je kao rukometni trener radio u Njemačkoj, dok su Slaven Bilić i Aljoša Asanović radili kao nogometni treneri, prvi u Velikoj Britaniji, a drugi u Australiji. Nogometni je trener Nenad Bjelica osim u Poljskoj radio u Austriji i Italiji. Osim njih u inozemstvu su radili i vrlo eksponirani izbornik hrvatske nogometne reprezentacije Zlatko Dalić (u Ujedinjenim Arapskim Emiratima) te brojni drugi treneri, a neki i danas rade $u$ drugim zemljama, poput Ivana Leke, trenera belgijskoga nogometnog kluba Antwerp. Moguće je da su ispitanici sportske uspjehe sportaša iz olimpijskim odličjima bogatih zemalja, kao i sportske uspjehe hrvatskih sportaša i trenera, povezali s važnošću znanja engleskog, njemačkog, francuskog, talijanskog i španjolskog jezika u kontekstu rada u sportskome menadžmentu. Drugi je faktor očigledno faktor sportskih uspjeha $i$ visoke procijenjene važnosti stranih jezika za rad u sportskome menadžmentu.

Treći je faktor objašnjavao najmanji postotak ukupne varijance, no prosječna srednja vrijednost procijenjene važnosti znanja jezika koji su s tim faktorom imali najviše korelacije bila je srednja od tri. Moguće je tumačenje sljedeće: iako je iz zemalja (Rusija, Kina, Japan, Južna Koreja) u kojima se govore jezici s najvišim korelacijama s trećim faktorom, Hrvatsku u 2019. ukupno posjetilo najmanje turista, to su zemlje koje su osvojile drugi najveći prosječan broj olimpijskih odličja, no prema prosječnome BDP-u nalaze se na prvome mjestu od tri grupacije. Dobiveni rezultati mogu upućivati na sljedeći zaključak. Ako ih se promatra u opisanome turističkom kontekstu, tada postaje jasno da bi - možda/vjerojatno, više pozornosti trebalo posvetiti učenju kineskog, japanskog, korejskog te ruskog jezika. Na ovom se mjestu u tumačenje faktora može uključiti financijski aspekt, tj. snaga ekonomija pojedinih zemalja. Naime, Kina, Japan, Rusija i Južna Koreja nalaze se na 2., 3., 11. i 12. mjestu po BDP-u u 2019. (World Bank, 2020). Drugim riječima, što se turizma tiče, valjalo bi pojačati promociju hrvatskog turizma u tim zemljama kako bi one postale još bolja emitivna turistička tržišta za Hrvatsku. Nadalje, uzme li se u obzir aspekt opisanih (ali i nekih drugih o kojima ovdje nije bilo riječi) uspjeha sportaša koji dolaze iz tih zemalja i interes kineziologa za sport, ali i za zapošljivost u njihovoj struci 
u zemljama koje za sport izdvajaju znatna financijska sredstva, dolazi se do prilično jasne pozadine trećeg faktora. Treći je faktor stoga, kako je to i u prvom tumačenju dobivenih faktora pretpostavljeno, faktor jakih svjetskih ekonomija i srednje procijenjene važnosti stranih jezika za rad u sportskome menadžmentu.

Takvo bi se tumačenje latentnih dimenzija moglo protumačiti kao implicitno povezivanje mogućih stereotipa o zemljama ciljnog jezika (engl. target language country) i instrumentalne orijentacije unutar motivacije za učenjem engleskog kao L2 - o kojoj prvi pišu Gardner i Lambert (1959), a o čemu je istraživanje provela Nikitina (2019). Međutim, to će tumačenje ostati na razini pretpostavke jer za korelaciju između stereotipa o zemljama ciljnog jezika i instrumentalne orijentacije u ovome istraživanju, s obzirom na metodologiju istraživanja, nema empirijskih podataka.

\subsection{Multivarijatna analiza varijance}

Za svaki su faktor izračunati faktorski skorovi te su tako dobivene tri nove varijable koje su u nastavku istraživanja u multivarijatnoj analizi varijance (MANOVA) poslužile kao zavisne, dok je nezavisna varijabla u toj analizi bila broj stranih jezika koje su ispitanici učili tijekom života (1, 2, 3 i 4). MANOVA je pokazala da nije bilo razlika među ispitanicima s obzirom na broj stranih jezika koje su učili u procjeni važnosti znanja 15 stranih jezika iz mjernog instrumenta $-F(9,155,91)=1,410, p=0,188$. To, drugim riječima, znači da su ispitanici vrlo slično procijenili važnost znanja svakog od 15 jezika iz mjernog instrumenta neovisno o tome koliko su stranih jezika učili. Očigledno je da broj stranih jezika nije bio odlučujući kriterij u toj procjeni, stoga se može pretpostaviti da su ispitanici u kontekstu stručnoga studijskog okruženja usvojili stavove o važnosti pojedinih jezika uzimajući u obzir brojne aspekte koji utječu na posao sportskih menadžera. S obzirom na to da nacrt ovog istraživanja nije predvidio ispitati studentske stavove o razlozima njihovih procjena važnosti znanja pojedinih stranih jezika, o njima se može samo nagađati. Unatoč izostanku statistički značajne razlike u multivarijatnoj analizi varijance, moguće je razmotriti prikaz srednjih vrijednosti najmanjih kvadrata za tri faktora s obzirom na broj stranih jezika koje su ispitanici učili (Slika 2.), što bi moglo pomoći u dodatnom pojašnjenju dobivenog rezultata.

Studenti i studentice koji su učili dva strana jezika najmanje su oscilirali u procjeni važnosti stranih jezika na sva tri faktora, a nešto su veću važnost pripisali jezicima koji su najviše korelacije uspostavili s trećim faktorom 
(japanski, korejski, kineski, ruski). To su ispitanici koji su učili dva strana jezika (usp. Tablicu 4.), i to iz skupine jezika s najvišim korelacijama s drugim faktorom. Vjerojatno im se znanje kineskog, japanskog, korejskog i/ili ruskog činilo nešto važnijim zbog mogućnosti zapošljavanja u zemljama u kojima su to službeni jezici. Malo su veće oscilacije bile kod ispitanika koji su učili tri strana jezika, pri čemu je otklon bio najveći za prvi faktor, odnosno za jezike koji su s njime imali najviše korelacije (češki, slovački, poljski, mađarski, norveški, švedski). To pak znači da su u kontekstu sportskog menadžmenta znanje navedenih jezika smatrali važnijima od znanja drugih stranih jezika u mjernom instrumentu. Tumačenje takvog rezultata bi moglo ići u smjeru svijesti o potrebi ovladavanja službenim jezicima zemalja koje su geografski bliže Hrvatskoj (nalaze se u Europi), što možda implicitno ukazuje na percepciju rada u ponudi sportskih i rekreacijskih sadržaja u hrvatskom turizmu s obzirom na dva čimbenika - broj turista iz zemalja u kojima su ti jezici službeni i sve češća želja turista - bez obzira na zemlju iz koje dolaze, za aktivnim odmorom (usp. Marušić i sur., 2017: 31).

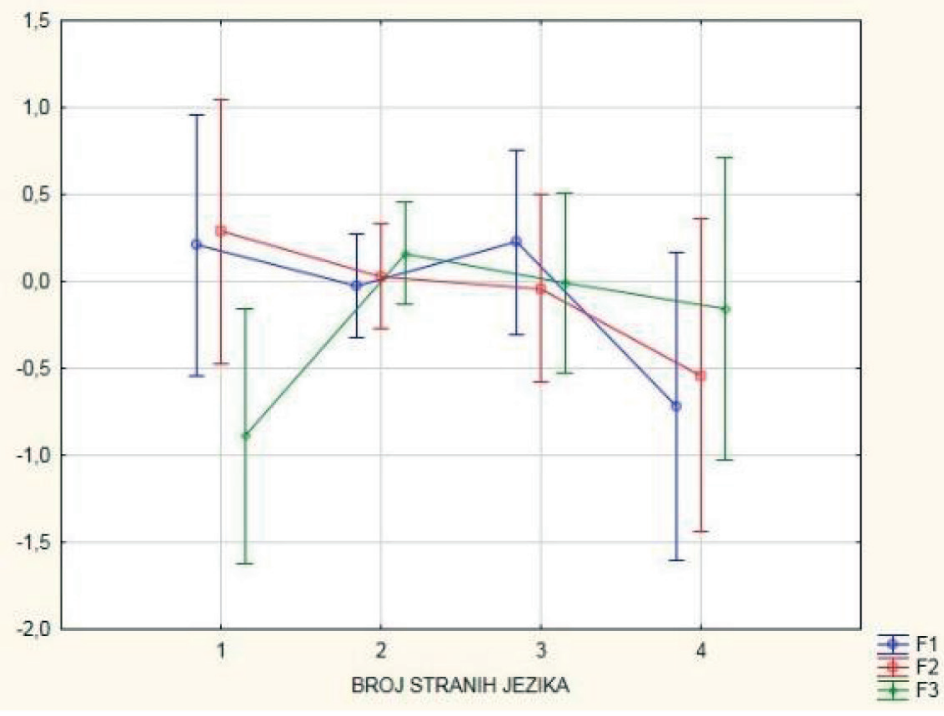

Slika 2. Prikaz srednjih vrijednosti najmanjih kvadrata za tri faktora

Odstupanja u procjeni još su nešto veća kod ispitanika koji su učili četiri strana jezika, a ukazuju na procjenu veće važnosti znanja jezika s najvišim korelacijama s trećim faktorom, što se poklapa s rezultatom ispitanika koji su učili dva strana jezika, i to vjerojatno s istim motivima. Zanimljivo je kako ispitanici koji su učili samo jedan strani jezik - i to engleski, najvaž- 
nijim za sportske menadžere procjenjuju znanje jezika koji su imali najviše korelacije s drugim faktorom (engleski, njemački, francuski, talijanski, španjolski), a najmanje važnim japanski, kineski, korejski i ruski. Moguća je pretpostavka da ti ispitanici osjećaju kako znanje jednoga stranog jezika nije dovoljno za posao menadžera u domeni sporta, te implicitno iskazuju stav o potrebi ovladavanjem još nekim jezicima iz te skupine. Izgledno je da oni znanje jezika poput češkog, slovačkog, poljskog, švedskog i norveškog slično kao kod ispitanika koji su učili tri strana jezika, povezuju s turistima iz zemalja u kojima su ti jezici službeni i sa sportsko-rekreacijskom ponudom. Rezultat da su ispitanici koji su učili samo jedan strani jezik najmanju važnost pridali znanju jezika kao što su kineski, japanski, korejski i ruski najvjerojatnije je odraz toga kako im se čini prioritetnim naučiti one strane jezike čije se znanje učestalije traži na tržištu rada, barem što se Hrvatske tiče.

No ukupno gledano, te su razlike bile vrlo male, što je rezultiralo izostankom statički značajne razlike u percepciji važnosti znanja pojedinih jezika s obzirom na broj stranih jezika koje su ispitanici učili tijekom života. Takav je rezultat u velikoj mjeri u skladu s aspektima koji se mogu iščitati iz faktorske analize i time upotpunjuje cjelokupno istraživanje.

\section{ZAKLJUČAK}

Ovo je istraživanje uz očekivane donijelo i neke manje očekivane rezultate. Ispitanici su, očekivano, znanje engleskog i njemačkog jezika procijenili najvažnijim za rad u sportskome menadžmentu. Očekivani rezultat je bio i taj da su ispitanici najčešće učili ta dva strana jezika te da su ih učili u prosjeku najveći broj godina. Ta dva strana jezika po procijenjenoj važnosti slijede talijanski, španjolski i francuski. Manje očekivani rezultat bio je taj da su se u uzorku našli ispitanici koji su učili tri pa čak i četiri strana jezika. Pri tome je trajanje učenja trećeg i četvrtog jezika bilo najkraće.

Sljedeći doprinos ovog istraživanja bila je interpretacija rezultata faktorske analize i to zbog toga što su se latentne dimenzije oblikovale na temelju aspekata turizma, sportskih uspjeha sportaša te gospodarske snage zemalja kojih su službeni jezici bili uključeni u mjerni instrument. Za razliku od prvog faktora koji je dobio atribut turistički i na kojem su se s najvišim faktorskim opterećenjima našli češki, slovački, poljski, mađarski, norveški i švedski, čija je procijenjena važnost znanja za rad u sportskome menadžmentu bila niska, na drugom su se faktoru koji je imao atribuciju sportskih uspjeha s najvišim faktorskim opterećenjima našli engleski, njemački, španjolski, 
francuski i talijanski kao strani jezici čije su znanje ispitanici ocijenili visokim ocjenama u kontekstu važnosti za rad u toj domeni. Treći je dobiveni faktor opisan kao faktor jakih svjetskih ekonomija, a na njemu su se našli ruski, kineski, japanski i korejski kao strani jezici čije je znanje procijenjeno srednje važnim za rad u sportskome menadžmentu, što je također jedan od elemenata koji nisu bili očekivani.

Posljednji doprinos analize ogleda se u rezultatu koji govori o tome da broj stranih jezika koje su ispitanici učili nije za posljedicu imao razlike u percepciji važnosti učenja pojedinih stranih jezika za rad u sportskome menadžmentu. Takav rezultat govori u prilog svijesti ispitanika o aspektima koji su se pokazali faktorskom analizom i zaokružuje nacrt cijelog istraživanja.

Iako razlozi za učenje pojedinih stranih jezika u ovom istraživanju nisu bili predmetom analize, implicitna priroda dobivenih latentnih dimenzija omogućila je - s obzirom na profesionalnu orijentaciju ispitanika, a to je kineziologija koje je sport sastavni dio, njihovo tumačenje. Njihova tumačenja pronađena su u kontekstu sporta kao globalnoga društvenog fenomena, velikih sportskih uspjeha hrvatskih sportaša, ali i sportaša iz drugih zemalja, zatim turizma, koji na svjetskoj razini generira ogromne financijske učinke i u kojemu Hrvatska sudjeluje s najvećim udjelom u BDP-u od svih europskih zemalja te ekonomskog čimbenika vezanog za zapošljivost i prihode na tržištima rada. Je li takva interpretacija utemeljena, pitanje je koje ukazuje na neke od mogućih pravaca daljnjih istraživanja. Drugim riječima, buduća bi se istraživanja važnosti znanja stranih jezika u domeni sportskog menadžmenta mogla orijentirati na razloge za učenje pojedinih stranih jezika. Među njima bi se mogle naći mogućnosti strukovnog i znanstvenog razvoja, mogućnosti promjene radnog mjesta i mjesta stanovanja, mogućnosti napredovanja itd. Moguće je u budućnosti provesti i istraživanje o postojanju razlika između studentske procjene važnosti znanja stranih jezika za rad u sportskome menadžmentu, s jedne strane, i s druge strane za rad nastavnika tjelesne i zdravstvene kulture ili za rad na nekome drugom radnom mjestu izvan domene sportskog menadžmenta.

\section{LITERATURA}

Amirovna, K. A. i Rustamovna, R. A. (2014) English language training volunteer program as a new reality for Russia and its social benefits. Procedia - Social and Behavioral Sciences 152, 1101-1107. doi: 10.1016/j.sbspro.2014.09.282

Bartoluci, M. (1995) Uloga športa i rekreacije u razvitku hrvatskog turizma. Tourism and Hospitality Management 1 (2), 253-265. https://hrcak.srce.hr/182526 (15. 9. 2020.). 
Bartoluci, M., Škorić, S. i Starešinić, Z. (2016) Sports tourism offer in Croatia. Poslovna izvrsnost 10 (2), 9-25. https://hrcak.srce.hr/170723 (15. 9. 2020.).

Bondrea, M. (2012) Public relations in sports management. Journal of Applied Economic Sciences (JAES) 7 (22), 361-365.

Business Wire. (2020) Sports - \$614 billion global market opportunities \& strategies to 2022. ResearchAndMarkets.com. https://www.businesswire.com/news/home/20190514005472/ en/Sports---614-Billion-Global-Market-Opportunities (15. 9. 2020.).

Chiswick, B. R. (2008) The economics of language: An introduction and overview. IZA Discussion paper No. 3568. doi: 10.1111/j.0042-7092.2007.00700.x

Chiswick, B. R. i Miller, P. W. (1995) The endogeneity between language and earnings: International analyses. Journal of Labor Economics 13 (2), 246-288.

Chiswick, B. R. i Miller, P. W. (2010) Occupational language requirements and the value of English in the US labor market. Journal of Population Economics 23 (1), 353-372. doi: 10.1007/s00148-008-0230-7

Çiftçi, S. i Mirzeoğlu, N. (2014) The research of qualifications of sport manager. Procedia Social and Behavioral Sciences 152, 740-745. doi : 10.1016/j.sbspro.2014.09.313

Çolak, S., Erdal, R., Başaran, Z., Çolak, E., Malkoç, N., Tekin Orha, A. i Tavas, O. (2018) Investigation of the communication skill levels of sports club managers. The Journal of International Anatolia Sport Science 3 (3), 319-324. doi: 10.5505/jiasscience.2018.29392

Čolić, D. N. i Tomić, M. (2013) Značaj učenja stranog jezika iz perspektive turističke industrije. TIMS Acta 7, 137-143. doi: 10.5937/timsact7-4543

De Knop, P. i Van Hoecke, J. (2003) The place of sport in the battle for the tourist: A figurational perspective of the development of sport tourism. Kinesiology 35 (1), 59-71. https://hrcak. srce.hr/226334 (15. 9. 2020.).

Državni zavod za statistiku Republike Hrvatske. (2020a) Priopćenje - Osnovne škole kraj šk. g. 2018./2019. i početak šk. g. 2019./2020., 57, 8.1.2. od 20. travnja 2020. https://www.dzs. hr (20.7. 2020.)

Državni zavod za statistiku Republike Hrvatske. (2020b) Priopćenje - Srednje škole kraj šk. g. 2018./2019. i početak šk. g. 2019./2020., 57, 8.1.3. od 20. travnja 2020. https://www.dzs.hr (20. 7. 2020.)

Dustmann, C. i Fabbri, F. (2003) Language proficiency and labor market performance of immigrants in the UK. The Economic Journal 113 (489), 695-717. https://www.jstor.org/ stable/3590195 (15. 9. 2020.).

Gardner, R. C. i Lambert, W. E. (1959) Motivational variables in second-language acquisition. Canadian Journal of Psychology / Revue Canadienne de Psychologie 13 (4), 266-272. doi: 10.1037.h0083787

Gibson, H. (1998) Active sport tourism: Who participates? Leisure Studies 17 (2), 155-170. doi: $10.1080 / 026143698375213$

Harrison-Hill, T. i Chalip, L. (2005) Marketing sport tourism: Creating synergy between sport and destination. Sport in Society 8 (2), 302-320. doi: 10.1080/17430430500102150

Jovanova-Simeva, V. (2015) The connection between top managers education and their successful sport clubs management. Research in Kinesiology 43 (1), 11-15.

Ko, L.-M., Henry, I. i Kao, J. C.-H. (2011) The perceived importance of sport management competencies by academics and practitioners in the cultural/industrial context of Taiwan. Managing Leisure 16 (4), 302-317. doi: 10.1080/13606719.2011.613628 
Kostić Bobanović, M. i Gržinić, J. (2011) The importance of English language skills in the tourism sector: A comparative study of students/employees perceptions in Croatia. Almatourism 2 (4), 10-23. doi: 10.6092/issn.2036-5195/2476

Leslie, D. i Russell, H. (2005) The importance of foreign language skills in the tourism sector: A comparative study of student perceptions in the UK and continental Europe. Tourism Management 27 (6), 1397-1407. doi: 10.1016/j.tourman.2005.12.016

Marušić, Z., Čorak, S. i Sever, I. (2017) Ljeto TOMAS 2017 Stavovi i potrošnja turista u Hrvatskoj. Zagreb: Institut za turizam.

Menike, Y. H. J. M. i Pathmalatha, K. M. (2015) Developing foreign language competencies of tourism industry oriented undergraduates in Sri Lanka. Tourism, Leisure and Global Change 2, TOC-74. https://www2.nau.edu/nabej-p/ojs/index.php/igutourism/article/ view/284/143 (15. 9. 2020).

Ministarstvo turizma Republike Hrvatske. (2020) Turizam u brojkama 2019. Ministarstvo turizma Republike Hrvatske. www.mint.hr (20. 7. 2020.).

Nikitina, L. (2019) Do country stereotypes influence language learning motivation? A study among foreign language learners in Malaysia. Moderna språk 113 (1), 58-79. http://ojs. ub.gu.se/ojs/index.php/modernasprak/article/view/4675 (15. 9. 2020).

Orel Frank, T. (2016) Recent research in the field of the interrelation of foreign languages and the field of tourism: Report from the 3rd international conference foreign languages and tourism. Academica Turistica 9 (2), 119-121.

Orsini, K. i Ostojić, V. (2018) Croatia's tourism industry: Beyond the sun and sea. Economic brief 036. Luxembourg: European Commission, Publication Office of the European Union. https://ec.europa.eu/info/publications/economic-and-financial-affairs-publications_en (15. 9. 2020.).

Prachanant, N. (2012) Needs analysis on English language use in tourism industry. Procedia Social and Behavioral Sciences 66, 117-125. doi: 10.1016/j.sbspro.2012.11.253

Rajković Iveta, M. i Babić, D. (2018) Poljaci u Hrvatskoj: od pripadnika 'stare' nacionalne manjine do suvremenih migranata. Studia ethnologica Croatica, 30, 169-202. https:// hrcak.srce.hr/214375 (15. 9. 2020.).

Retar, I., Plevnik, M. i Kolar, E. (2013) Key competences of Slovenian sport managers. Annales Kinesiologiae 4 (2), 81-94. http://ojs.zrs-kp.si/index.php/AK/article/view/10 (15. 9. 2020.).

Sindik, J. i Božinović, N. (2013) Importance of foreign languages for a career in tourism as perceived by students in different years of study. Tranzicija 15 (31): 16-28. https://hrcak. srce.hr/108361 (15. 9. 2020.).

Statista. (n. d.) Countries with the highest share of GDP generated by direct travel and tourism worldwide in 2019. https:/www.statista.com/statistics/1100368/countries-highest-gdptravel-tourism/ (15. 9. 2020.).

Sunay, H. i ve Çayci, E. (2008) The opinions of teams from Ankara which rank in different football categories about the qualification of sports management. Journal of Sportsmeter Physical Education and Sports Sciences 6 (2), 45-48.

Škorić, S. (2008) Sportski turizam i njegovi učinci na turističke destinacije - primjer Istre. Acta Turistica 20 (1), 67-92. https://hrcak.srce.hr/76249 (15. 9. 2020.).

Škorić, S. (2018) Characteristics of sport managers and challenges facing sport organisations. U Načinović Braje, I., Jaković, B. i Pavić, I. (ur.) An enterprise Odyssey: Managing change 
to achieve quality development. Zagreb: University of Zagreb Faculty of Economics \& Business, 497-503.

UNWTO - World Tourism Organization. (2019) International Tourism Highlights, 2019 Edition. Madrid: UNWTO. doi: 10.18111/9789284421152.

Uvinha, R. R., Chan, C.-S., Man, C. K. i Marafa, L. M. (2018) Sport tourism: A comparative analysis of residents from Brazil and Hong Kong. Revista Brasileira de Pesquisa em Turismo 12 (1), 180-206. doi: 10.7784/rbtur.v12i1.1374

World Bank. (2020) Gross domestic product 2019. https://databank.worldbank.org/data/ download/GDP.pdf (19. 8. 2020.).

World Population Review. (2020) Olympic medals by country 2020 by population 2020. https://worldpopulationreview.com/country-rankings/olympic-medals-by-country (19. 8 . 2020.).

World Sport Tourism Show. (n. d.) Numbers of sport tourism. https://www.wst-show.com/en/ sport-tourism (19. 8. 2020.).

World Travel \& Tourism Council. (n. d.) Economic Impact Reports. https://wttc.org/Research/ Economic-Impact (15. 9. 2020.).

Zhang, R. i McCornac, D. C. (2014) Challenges for the international tourism industry in Japan - An agent for economic recovery and development. Almatourism 5 (10), 109-124. doi: 10.6092/issn.2036-5195/4776

\section{PRILOG 1}

Broj hrvatskih osnovno- i srednjoškolaca koji uče navedene strane jezike

\begin{tabular}{ll|l|l}
\hline JEZIK & OSNOVNE ŠKOLE* & SREDNJE ŠKOLE** & UKUPNO \\
\hline Engleski & 299751 & 135602 & 435353 \\
\hline Njemački & 101595 & 52666 & 154261 \\
\hline Talijanski & 24541 & 19773 & 44314 \\
\hline Francuski & 2437 & 5532 & 7969 \\
\hline Španjolski & 329 & 2453 & 2782 \\
\hline Mađarski & 592 & - & 592 \\
\hline Češki & 271 & - & 271 \\
\hline Slovački & 326 & 41 & 367 \\
\hline Ruski & 43 & 199 & 242 \\
\hline Arapski & - & 73 & 73 \\
\cline { 2 - 4 }
\end{tabular}

* Državni zavod za statistiku Republike Hrvatske (2020a).

** Državni zavod za statistiku Republike Hrvatske (2020b). 


\section{PRILOG 2}

Ukupan broj osvojenih olimpijskih odličja, mjesto zemlje na ljestvici BDP-a za 2019. i broj stranih turista u 2019. u hrvatskome turizmu

\begin{tabular}{|c|c|c|c|c|c|c|c|}
\hline ZEMLJA & 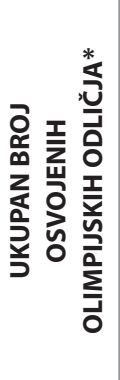 & 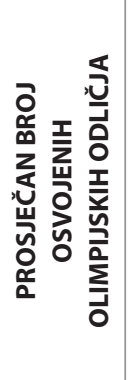 & 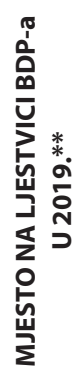 & 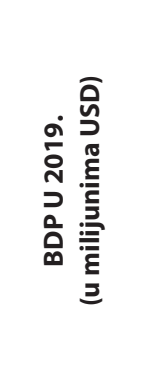 & 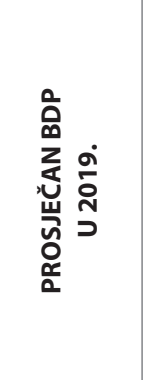 & 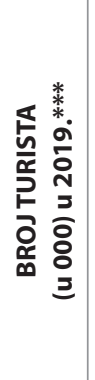 & 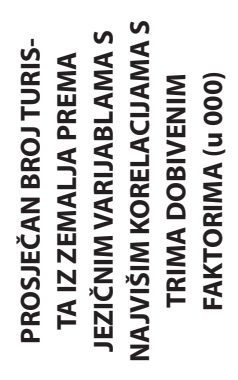 \\
\hline $\begin{array}{l}\text { Velika } \\
\text { Britanija }\end{array}$ & 883 & \multirow{12}{*}{601,17} & 6. & 2827113 & \multirow{12}{*}{1463420} & 859 & \multirow{12}{*}{695,33} \\
\hline SAD & 2827 & & 1. & 1427700 & & 626 & \\
\hline Australija & 12 & & 14. & 1392681 & & 217 & \\
\hline Novi Zeland & 120 & & 52. & 206929 & & 41 & \\
\hline Njemačka & 855 & & 4. & 3845630 & & 2881 & \\
\hline Austrija & 319 & & 14. & 446315 & & 1385 & \\
\hline Francuska & 840 & & 7. & 2715518 & & 629 & \\
\hline Belgija & 154 & & 24. & 529607 & & 211 & \\
\hline Luksemburg & 4 & & 72. & 71105 & & 11 & \\
\hline Italija & 701 & & 8. & 2001244 & & 1175 & \\
\hline Švicarska & 345 & & 20. & 703082 & & 268 & \\
\hline Španjolska & 154 & & 13. & 1394116 & & 309 & \\
\hline Češka & 87 & \multirow{6}{*}{349,83} & 47. & 246489 & \multirow{6}{*}{339868,5} & 742 & \multirow{6}{*}{533} \\
\hline Slovačka & 36 & & 61. & 105422 & & 439 & \\
\hline Poljska & 306 & & 21. & 592164 & & 933 & \\
\hline Mađarska & 498 & & 56. & 160967 & & 617 & \\
\hline Norveška & 520 & & 30. & 403336 & & 177 & \\
\hline Švedska & 652 & & 23. & 530833 & & 290 & \\
\hline Rusija & 546 & \multirow{4}{*}{497} & 11. & 1699877 & \multirow{4}{*}{$\begin{array}{c}5691 \\
733,25\end{array}$} & 139 & \multirow{4}{*}{243} \\
\hline Japan & 497 & & 3. & 5081770 & & 150 & \\
\hline Kina & 608 & & 2. & 14342903 & & 279 & \\
\hline $\begin{array}{l}\text { Koreja } \\
\text { (Južna) }\end{array}$ & 337 & & 12. & 1642383 & & 404 & \\
\hline
\end{tabular}




\title{
Quantitative analysis of students' assessment of the importance of foreign languages in sports management
}

\author{
Darija Omrčen \\ darija.omrcen@kif.hr \\ Faculty of Kinesiology, University of Zagreb \\ Magdalena Mihovec \\ mihovec7@gmail.com \\ T. O. MODA-IN
}

\begin{abstract}
The aim of the analysis was to find out how future kinesiologists assess the importance of 15 foreign languages in sports management. The sample was comprised of 70 male and female students from the Faculty of Kinesiology, University of Zagreb. The results showed that most of the students had learned English and German, and for the longest period. As many as $62.86 \%$ had learned two foreign languages, whereas $20 \%$ had learned three, $10 \%$ had learned only one, and only $7.14 \%$ had learned four foreign languages. The students assessed the command of English and German as the most important asset for work in sports management. The factor analysis yielded three latent dimensions interpreted on the basis of the aspects of tourism, success in sport, and economic power. By means of factor scores of the three obtained factors, a multivariate analysis of variance did not show differences between students' assessment of the importance of the 15 foreign languages based on the number of foreign languages they had learned.
\end{abstract}

Keywords: assessment of importance, foreign languages, sports management, tourism 